\title{
Formulation technologies of orally fast disintegrating tablets
}

\author{
Yağmur Bircan', Tansel Çomoğlu²
}

\begin{abstract}
Methods to improve patient's compliance have always attracted scientists towards the development of new drug delivery systems. Among them, orally fast disintegratings tablets (FDTs), have acquired an important place in the drug market by overcoming previously encountered administration problems and contributing to extension of patent life. FDTs have the unique property of rapidly disintegrating and/or dissolving and releasing the drug as soon as they come in contact with saliva. Therefore, these tablets are very practical for the patient population that include bed ridden, dysphagic, geriatric or pediatric and phychic patients.
\end{abstract}

This article focuses on the technologies available and the advances made so far in the field of fabrication of FDTs along with their advantages and limitations.

KEY WORDS: orally fast disintegrating tablets, formulation technologies of orally fast disintegrating tablets

\section{INTRODUCTION}

Oral delivery is currently the gold standard in the pharmaceutical industry where it is regarded as the safest, most convenient and an economical method of drug delivery having the highest patient compliance. Tablets are the most widely utilised oral dose format. Tablets that disintegrate or dissolve rapidly in the patient's mouth offers the ease of oral administration and benefits of increased patient compliance and are practical for young children, the elderly and patients having swallowing difficulties (dysphagia) and tremor of extremities or mentally retarded. Dysphagia is common in about $35 \%$ of the general population, as well as an additional $30-40 \%$ of elderly institutionalized patients and $18-22 \%$ of all persons in long-term care facilities $(1,2)$. Fast disintegrating tablets (FDTs) have received ever increasing demand during the last decade, and the field has become a rapidly growing area in the pharmaceutical industry. Upon introduction into the mouth, these tablets dissolve or disintegrate in the mouth in the absence of additional water (1).
Some FDTs are designed to dissolve in the saliva usually within $<60$ seconds. Others contain agents to enhance the rate of the tablet disintegration in the oral cavity, and are more appropriately termed fast-disintegrating tablets, as it may take up to a minute to a complete disintegration (3). In Figure 1 the diagram of disintegration behavior of FDTs after oral intake is shown.

They have all the advantages of solid dosage forms, such as good stability during storage, possessing dose accuracy, easy manufacturing, small packaging size and easy handling by patients. FDTs also have the advantages of liquid formulations, such as easy administration and no risk of suffocation resulting from physical obstruction by a dosage form. Because FDTs disintegrate inside the mouth, drugs may be absorbed in the buccal, pharyngeal, and gastric regions and this may help to improve bioavaliability of a drug compared to conventional tablet forms (5). FDTs have several characteristics to distinguish them from the more traditional dosage forms, taste-masking
AFFILIATIONS

${ }^{1}$ Ankara Üniversitesi, Eczacılık Fakültesi, 5. sınıf Öğrencisi, Ankara, Türkiye

2Ankara Üniversitesi, Eczacılık Fakültesi, Farmasötik Teknoloji Anabilim Dalı, Ankara, Türkiye

\section{CORRESPONDENCE}

Tansel Çomoğlu

E-mail:

tcomoglu@yahoo.com

Received:

18.04.2011

Revision:

25.08.2011

Accepted:

21.09.2011 


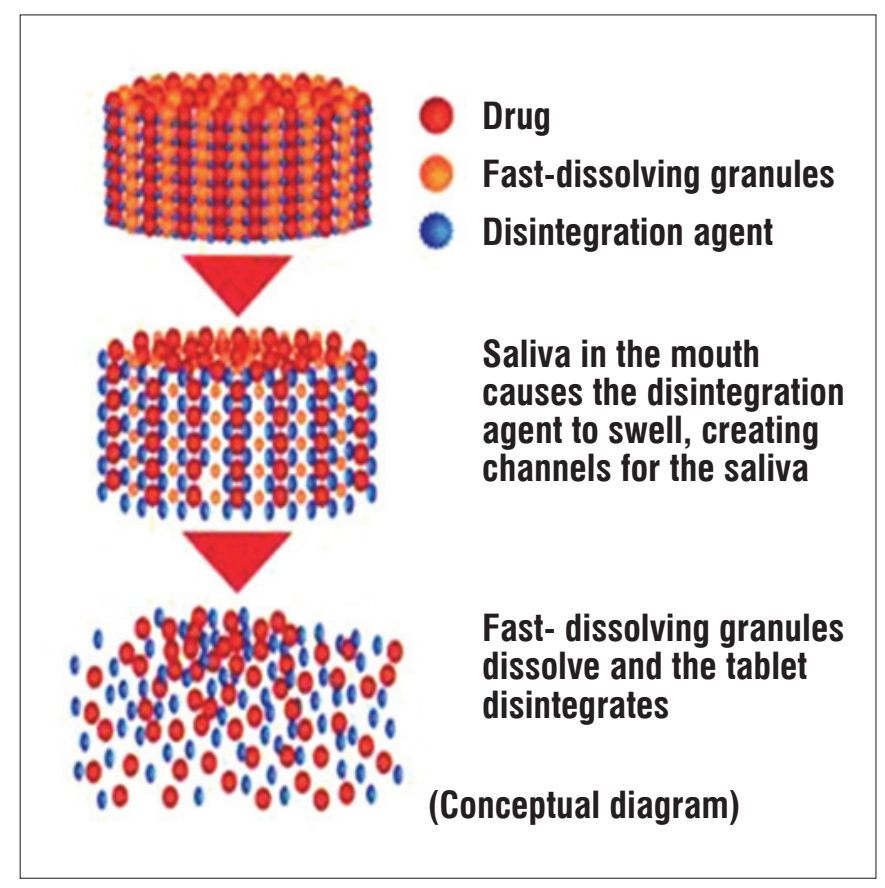

FIGURE 1. Disintegration of FDTs after oral intake (Web 2, Amrutha, 2009-Fast Dissolving Tablets-Pharmainfo.net )

is of critical importance in the formulation of an acceptable FDT. Traditional tablet formulations generally do not address the issue of taste masking, because it is assumed that the dosage form will not dissolve until passing the oral cavity. Many oral suspensions, syrups, and chewable tablets simply contain flavors, sugars and other sweeteners to mask or complement the bitter taste of the drug. Current methods of taste masking in fast dissolving/disintegrating tablets include sweeteners and flavors; however, these are not a sufficient means for tastemasking many bitter drugs. Most of the FDT technologies use unique forms of taste masking as well. The primary methods of taste-masking include adsorption onto or complexation with carriers and spray coating of drug particles $(3,6)$.

\section{CURRENTLY AVAILABLE TECHNOLOGIES USED FOR FDT FORMULATIONS}

FDTs can be prepared by various conventional methods like direct compression, moulding, spray drying, freeze drying, and sublimation. As these methods are explained in detail by several authors (1, 7-9) only brief information about these production methods but examples of marketted products and some studies on FDTs will be given here.

\section{Direct Compression}

Especially from the pharmaceutical manufacturer's aspect, direct compression is the simplest tablet manufacturing procedure. Direct compression method can easily be applied to manufacturing FDTs by choosing appropriate combinations of excipients (1). The major difference is that FDTs are compressed at much lower forces $(4-20 \mathrm{kN})$ than the traditional tablets (10).

\section{Moulding}

Tablets that are produced with moulding method contain water soluble ingredients in order to dissolve completely and rapidly. There are some different moulding techniques such as; compression moulding process, heat moulding process and moulding by vacuum evaporation without lyophilization (11). Major advantage of this techique is that as the dispersion matrix is made from water soluble sugars, moulded tablets disintegrate more rapidly and offer improved taste but disadvantage of this method is that the moulded tablets have poor mechanical strength, so they may undergo erosion and breaking during handling (8).

\section{Spray Drying}

Tablets which are manufactured from the spray-dried powder have been reported to disintegrate in less than 20 seconds in aqueous medium. The formulation contained bulking agent like mannitol and lactose, a superdisintegrant like sodium starch glycolate and croscarmellose sodium and acidic ingredient (citric acid) and/or alkaline ingredients (e.g. sodium bicarbonate). This spray-dried powder, which compressed into tablets showed rapid disintegration and enhanced dissolution. Maximum drug release and minimum disintegration time were observed with Kollidon CL excipient base as compared to tablets prepared by direct compression, showing the superiority of the spray dried excipient base technique over direct compression technique $(7,12)$.

\section{Freeze Drying}

Freeze drying (lyophilization) is a process in which solvent is removed from a frozen drug solution or a suspension containing structure-forming excipients. The resulting tablets are usually very light and have highly porous structures that allow rapid dissolution or disintegration. One of the main advantages of this method is, when stored in a dried state, the freeze-dried dosage form has relatively few stability problems during its shelf life.The freeze-drying process may result in a glassy amorphous structure of excipients as well as the drug substance, leading to the enhanced dissolution rate. Freeze drying, however, is a relatively expensive manufacturing process, and the formulation has poor stability at higher temperature and humidity $(1,13)$.

\section{Sublimation}

Sublimation has been used to produce FDTs with high porosity. A porous matrix is formed by compressing the volatile ingredients along with other excipients into tablets, which are finally subjected to a process of sublimation. Inert solid ingredients with high volatility (e.g., ammonium bicarbonate, ammonium carbonate, benzoic acid, camphor, hexamethylene tetramine, naphthalene, phthalic anhydride, urea and urethene) have been used for this purpose (14). Solvents such as cyclohexane and benzene were also suggested for generating the porosity in the matrix. Makino et al.,reported a method using water as a pore-forming material (15).

Comoglu prepared FDTs of carbamazepine and investigated the effects different superdisintegrants; Ludiflash ${ }^{\circledR}$ and Ac-Di$\mathrm{Sol}^{\circledR}$ using two different compression pressure values (10). Also, Comoglu et al., investigated the analgesic effect and the time to relieve migraine headache between the commercial tablets and FDTs of diclofenac potassium prepared by direct compression aganist placebo. Placebo controlled in vivo trial demonstrated that $50 \mathrm{mg}$ diclofenac potassium, administered as a single dose of FDTs or commercial tablets, was effective in relieving the pain and both of them were superior to placebo 
(16). Remon and Corveleyn studied the influence of various formulation and process parameters on the characteristics of fast disintegrating tablets prepared by freeze drying method and informed that maltodextrins are useful in FDT formulations made by freeze drying (17). Sunada and Bi used both direct compression, kneading and wet compression to prepare FDTs of ethenzamide and ascorbic acid and investigated the tablet properties (18).

There are also some patented technologies to produce FDTs. In 1986, Cardinal Health was the first company to develop and market a lyophilized fast-dissolving technology Zydis ${ }^{\circledR}(5,7)$. In Zydis ${ }^{\circledR}$ technology, the drug is physically trapped in a matrix composed of two components, a saccharide (e.g., mannitol) and a polymer. The carrier polymers commonly used in the Zydis ${ }^{\circledR}$ system include (partially hydrolyzed) gelatin, hydrolyzed dextran, dextrin, alginates, poly(vinyl alcohol), polyvinylpyrrolidone, acacia, and mixtures thereof.

It is a requirement for the drug that it should be chemically stable and water insoluble, with a particle size smaller than 50 $\mu \mathrm{m}$ for this technology. There are more than thirteen products available in the drug market containing loratadine, piroxicam, famotidine, ondansetron, tepoxalin, selegiline, loratadine, clonazepam which are produced by Zydis ${ }^{\circledR}$ technology for various applications (19).

Then, CIMA Labs. marketted an effervescent tablet known as OraSolv ${ }^{\circledR}$ and by utilizing the conventional tableting equip- ment they also marketted DuraSolv ${ }^{\circledR}$ (20). Today, BristolMyers Squibb manufactures acetaminophen fast disintagrating tablets using OraSolv ${ }^{\circledR}$ technology and cisapride monohydrate FDTs are produced by Janssen by using Quicksolv ${ }^{\circledR}$ technology. DuraSolv ${ }^{\circledR}$ has the advantage of having a much higher mechanical strength but its limitation is low drug loading capacity $(1,21)$. AstraZeneca uses this technology to produce zolmitriptan FDTs for migraine treatment (1).

Others include Eisai and Ethypharm that developed the EMP tablet and Flashtab. Eisai Co. marketted donezepil ODTs for Alzheimer's disease (22). Flashtab contains coated crystals of drug and microgranules along with disintegrants. In this technology, disintegrants having high (eg: modified cellulose) and low (eg: starch) swelling capaties are used. Tablets produced with this technology have desirable physical resistance (1).

Yamaouchi patented the WowTab ${ }^{\circledR}$ technology. This technology is applicable for both soluble and insoluble drugs and utilizes granulation and tableting methods (23).

Lafon Labs. produced Lyoc ${ }^{\circledR}$ technology, which has a porous solid form that is obtained by freeze drying an oil-in-water emulsion placed directly in the blister pockets. In order to prevent inhomogeneity by sedimentation during freeze drying, It is a requirement for this technology to have a large proportion of undissolved inert filler to increase the viscosity of the suspension. The high proportion of filler reduces the porosity of the tablet, and as a result, the disintegration is slower. It is a disad-

TABLE 2. Some patented technologies of FDTs [Bihandari, 2008, Siddiqui et al., 2010]

\begin{tabular}{|c|c|c|c|}
\hline Technology & Process Involved & Patent Owner & Drugs Used (Brand Name) \\
\hline Zydis ${ }^{\circledR}$ & Lyophilization & R.P.Scherer & $\begin{array}{c}\text { Loratadine (Claritin Reditab and Demitapp } \\
\text { Quick Dissolve) }\end{array}$ \\
\hline Ouicksolv® & Lyophilization & Jansen Pharmaceuticals & $\begin{array}{c}\text { Cisapride monohydrate (Propulsid } \\
\text { Quicksolv), Risperidone (Risperdal M-tab) }\end{array}$ \\
\hline Flashtab® & Lyophilization & Ethypharm & Ibuprofen (Nurofen Flashtab) \\
\hline Lyoc $®$ & Freeze Drying & Laboratories L. Lafon & Phloroglucinol hydrate (Spasfon Lyoc) \\
\hline Orasolv $®$ & Compressed tablets & Cima Labs.Inc. & $\begin{array}{l}\text { Paracetamol (Tempra Quicklets), } \\
\text { Zolmitriptan (Zolmig Repimelt) }\end{array}$ \\
\hline Durasolv $®$ & Moulding & Cima Labs.Inc. & $\begin{array}{c}\text { Hyoscyamine sulfate (NuLev), Zolmitriptan } \\
\text { (Zolmig ZMT) }\end{array}$ \\
\hline RapiTab® & Compressed tablets & Schwarz Pharma & - \\
\hline Wowtab® & Compressed moulded tablets & Yamanouchi Pharma Tech. Inc. & Famotidine (Gaster D) \\
\hline Fast melt ${ }$ & Moulding & Elan Corp. & - \\
\hline Ziplets ${ }^{\circledR}$ & Moulding & Eurand & Ibuprofen (Cibalgina Due Fast) \\
\hline & & & Tramadol HCl (Relivia Flash dose) \\
\hline Flashdose $®$ & Cotton-candy process & Fuisz Tech.Ltd. & \\
\hline Oraquick $®$ & Micromask taste masking & KV Pharm.Co., Inc. & Hyoscyamine sulfate ODT \\
\hline Advatab® & Microcaps and diffuscap CR Tech. & Eurand International & AdvaTab Cetrizine, AdvaTab Paracetamol \\
\hline
\end{tabular}


TABLE 3. FDTs that are under development (Web 5)

\begin{tabular}{|c|c|c|c|}
\hline Formulation & Company & Brand name & Group \\
\hline Citalopram ODT & Biovail & Citalopram & SSRIS \\
\hline Metoclopramide Zydis & Salix Pharmaceuticals & Metoclopramide & Dopamine receptor antagonists \\
\hline Reglan ODT & Schwarz Pharma & Metoclopramide & Dopamine receptor antagonists \\
\hline Tramadol/Acetaminophen ODT & Biovail & Tramadol/Acetaminophen & Opioid analgesic [Tramadol] \\
\hline Zolpidem ODT & Biovail & Zolpidem & Nonbenzodiazepine Hypnotics \\
\hline
\end{tabular}

vantage of this technology that the tablet still has poor mechanical properties (13). In Nanonization technology, NanoCrystal ${ }^{R}$ colloidal dispersions of drug substance are combined with water-soluble ingredients, filled into blisters, and lyophilized. Nanoparticles $(<2 \mu \mathrm{m})$ are orally administered in the form of rapidly disintegrating tablet matrix. The NanoCrystal ${ }^{\mathrm{TM}}$ orally disintegrating tablet dosage form was developed to facilitate the absorption and the bioavailability of the drug. This technology has the advantage of wide dosing range (1).

There still is a continuous growth in names by different companies, and the technology is still improving.

Some patented technologies and their companies are listed in Table 2 and FDTs which are under development are shown in Table 3.

\section{FUTURE PERSPECTIVES OF ORALLY FAST DISINTEGRATING TABLETS}

FDT concept evolved to overcome some of the problems that existed in conventional dosage forms i.e. difficulty in swallowing of tablet in pediatric and geriatric patients. FDTs may lead to improve efficacy, biavailability, fast onset of action, better patient's compliance due to its quick absorption from mouth to GIT (24).

Despite these advances in the FDT technologies, there are still many aspects to improve and problems waiting to be solved in the FDT formulations. Formulation of hydrophobic drugs is still a challenge, especially when the amount of drug is high. The low dose drugs, pose little problem, but as the dose increases, the formulation sacrifices its fast disintegrating prop- erty. A new technology is being developed to incorporate higher doses of hydrophobic drugs without affecting the fast disintegrating property too severely. The disintegration times of most FDTs on the market are acceptable, but certainly there is a room for improvement. Because the disintegration time is related to other formulation variables, a balance has to be maintained between shortening the disintegration time and other tablet properties. The tablet hardness, friability, and stability can be further improved to such a level that multi-tablet packaging in conventional bottles becomes a norm.

The future of FDTs lies in the development of FDTs with controlled release properties. If one FDT can deliver drugs with short half-lives for 12-24 hours, it would be a quantum improvement in the FDT technology. The added convenience and compliance of such formulations would be enormous. The future of FDTs also lies in the development of effective tastemasking properties. The use of coating poorly tasting drugs is commonly used, but it increases the total volume of the final formulation. There may be no magic solution to this, but more effective use of existing taste masking technologies is expected to alleviate the problems associated with taste masking.

In addition, the ability to formulate drugs in large doses will bring another important technological advance. In general, the FDT formulations require large amounts of excipients, and having large doses of drug will only make the final formulation too big to handle. An FDT formulation that would require fewer excipients than the drug itself would be a breakthrough. While the problems to be solved are not easy, the history suggests that it is just a matter of time before they are solved (1).

\section{Ağızda hızlı çözünen tabletlerin formülasyon teknolojileri}

ÖZET: Hasta uyuncunu kolaylaştıracak metodların geliştirilmesi araştırmacıları yeni ilaç taşıyıcı sistemleri araştırmaya yönlendirmiştir. Bunlar arasında ağızda hızlı çözünen tabletler (FDTs), uygulama problemlerini aşmada ve patent süresinin uzatılmasına bulundukları katkı ile ilaç piyasasında önemli bir yer kazanmışlardır. FDT’ler tükrük ile temasta hızlı çözünme ve etkin madde salımına başlama özelliğine sahiptir. Bu nedenle, yutma güçlüğü çeken, yatağa bağımlı, geriatrik ve pediatrik hasta popülasyonu açısından son derece pratik kullanıma sahip tabletlerdir.

Bu çalışma, hızlı çözünen tabletlerin teknolojileri ile üretimlerinde şimdiye kadar kaydedilen gelişmeler ile birlikte üretim yöntemlerinin avantajları ve sınırlandırılmaları üzerine odaklanmaktadır.

ANAHTAR SÖZCÜKLER: ağızda hızlı çözünen tabletler, ağızda hızlı çözünen tabletlerin formülasyon teknolojileri 


\section{REFERENCES}

1. Fu Y, Yang S, Jeong SH, Kimura S, Park K. Orally fast disintegrating tablets: developments, technologies, tastemasking and clinical studies. Critical Reviews in Therapeutic Drug Carrier Systems. 2004; 21:433-75.

2. Mizumoto $T$, Yoshinori $M$, Yamamoto $T$, Yonemochi $E$, Terada K. Formulation design of a novel fast-disintegrating tablet. Int. J. Pharm. 2005; 306:83-90.

3. Biradar SS, Bhagavati ST, Kuppasad IJ. Fast dissolving drug delivery systems: A brief overview. The Internet Journal of Pharmacology. 2006; 4 (2), ISSN: 1531-2976 available on 25.01.2011

4. Amrutha K. Fast dissolving tablets. Pharmainfo.net, 04/11/2009; available on 15.04.2011

5. Seager H. Drug-delivery products and the Zydis fast-dissolving dosage form. J Pharm Pharmacol. 1998; 50:375-82.

6. Chang RK, Guo X, Burnside B, Couch R. Fast-Dissolving Tablets. Pharm Technol. 2000; 24:52-8.

7. Mishra DN, Bimodal M, Singh SK, Vijaya Kumar SG. Spray dried excipient base: a novel technique for the formulation of orally disintegrating tablets. Chem Pharm Bull. 2006; 54:99-102.

8. Shukla D, Chakraborty S, Singh S, Mishra B. Mouth dissolving tablets I: An overview of formulation technology. Sci Pharm. 2009; 77:309-26.

9. Shukla D, Chakraborty S, Singh S, Mishra B. Mouth dissolving tablets II: An overview of evaluation technologies. Sci Pharm. 2009; 77:327-41.

10. Comoglu T. Formulation and evaluation of carbamazepine fast disintegrating tablets. Pharmazeutische Industrie. 2010; 72:150-8.

11. Pebley WS, Jager NE, Thompson SJ. Rapidly disintegrating tablet. 1994; US Patent 5, 298, 261. March 29.

12. Gupta A, Mishra AK, Gupta $V$, Bansal $P$, Singh $R$, Singh AK. Recent Trends of Fast Dissolving Tablet - An Overview of Formulation Technology". International Journal of Pharmaceutical \& Biological Archives. 2010; 1:1-10.
13. Habib W, Khankari RK, Hontz J. Fast-dissolve drug delivery systems. Crit Rev Ther Drug Carrier Sys. 2000; 17: 61-72.

14. Koizumi KI, Watanabe $Y$, Morita K, Utoguchi N, Matsumoto M. New method for preparing high porosity rapidly saliva soluble compressed tablets using mannitol with camphor, a subliming material. Int J Pharm. 1997; 152:127-31.

15. Makino T, Yamada M, Kikuta JI. Fast-dissolving tablet and its production. 1998. US Patent 5,720,974., Feb 24.

16. Comoglu T, Dogan A, Comoglu S, Basci N. Formulation and evaluation of diclofenac potassium fast disintegrating tablets and their clinical application in migraine patients. Drug Development\&Industrial Pharmacy. 2011; 37:260-7.

17. Remon JP, Corveleyn S. Freeze-dried disintegrating tablets. 2000; US Patent, 6, 010, 719.

18. Sunada H, Bi Y. Preparation, evaluation and optimization of rapidly disintegrating tablets. Powder Technology. 2002; 122:188-98.

19. News Release, Scherer Announces Launch Of First U.S. Product Using Zydis ${ }^{\circledR}$ Technology. September 1996; available on 15.04.2011.

20. Shailesh S, Gupta GD, Bala R, Sharma N, Seth N, Goswami JP. Orodispersible tablet: A review. 29.03.2008; available on http://www.pharmainfo.net/reviews/ orodispersable-tablet-review Accessed: 15.04.2011.

21. Gole DJ, Levinson RS, Carbone J, Davies JD. Preparation of pharmaceutical and other matrix systems by solidstate dissolution. 1993; US Patent 5, 215,756.

22. Bihandari $D$, Agarwal $A$, Gupta $H$. Recent trends-Fast dissolving tablets. Latest Reviews. 2008; 6 (6).

23. Dobetti L. Fast-melting tablets: developments and technologies. Pharm Technol N Am. 2001; 44-50.

24. Siddiqui $M N$, Garg G, Sharma PK. Fast dissolving tablets: Preparation, characterization and evaluation: An overview. Int J Pharm Pharm Sci 2010;4: 87-96.

25. http:// en.wikipedia.org/wiki/Orally_disintegrating tablet. available on 15.04.2011. 